imposed upon and may not the authorship be totally different from that which he assumes? The delay which has occurred in carrying ont the negotiations for the incorporation of the London School of Medicine for Women, and which Professor Starling himself styles " discreditable," has no doubt led to many surmises, of one of which this quotation may be a far-off reflection. Such a surmise may quite naturally have been based on the fact that a large representation of University College is found to exist on the committee which deals with the incorporation of the London School of Medicine for Women. But on such slender evidence as he appears to possess, reaching him in such devious ways, Professor Starling is surely unjustified in rushing into print with vague charges of " underhand methods" and a general challenge to the Senate.

A further instance of hasty recrimination is afforded by some paragraphs of the letter from certain members of St. George's Hospital which follows the communication which $I$ have just mentioned and in which the candidates opposing Professor Starling are accused by implication of "urging the University to repudiate its obligations," and a statement in Mr. Wallis's address is bluntly characterised as "incorrect." Mr. Wallis has since issued a circular to the Faculty in which he produces incontestable evidence of the accuracy of his statement, based as it appears to have been on previous inquiry. Surely it was equally open to Professor Starling, who, in his election address, states that "the University is in honour bound " "by agreements with certain medical schools," and to the signatories of the St. George's letter, who make these serious charges of "repudiation of obligations," to ascertain the facts before publishing these accusations. Is it too much to hope that in future contests in the Medical Faculty the candidates will be content with a clear exposition of their policies and will avoid an acrimonious tone.

London, W., Nov, 11th, $190 \%$. I am, Sirs, yours faithfully.

JUSTITIA.

\section{POST-OPERATIVE LOCAL INFECTION IN CANCER AND TUBERCULOSIS.}

\section{To the Editors of THW LANCET.}

SIRS,-In a communication published in THE LANCET of last week Mr. Charles Ryall has drawn attention to the danger of infection with carcinoma in operations performed for the relief of the condition. Every surgeon must have met with cases of rapid local recurrences of the disease after operation and the disappointment they cause. There can be little doubt that in most instances the explanation of post-operative local infection given by $\mathrm{Mr}$. Ryall is the correct one. And in this connexion, which is yet but imperfectly appreciated, carcinoma presents a great similarity to tuberculosis. In $1905 \mathrm{Mr}$. L. S. Dudgeon and I read a paper to the Clinical Society on Post-operative Local Tuberculous Infection, which was printed in the Transactions and also in the Clinical Journal, 1905, pp. 206-208. In this communication we drew attention to the local tuberculous infection of healthy tissues which not infrequently resulted from operations undertaken for the eradication of tuberculous lesions, such as "glands" of the neck, arthrectomies of joints, \&c. As imperfect operations, such as erasions, are taught to be good practical surgery for tuberculosis and not for carcinoma, it follows naturally that post-operative local tuberculous infection is, and must be, a great deal more frequent than post-operative local carcinomatous infection. Yet, as Mr. Ryali, Mr. Dudgeon, and myself have urged, medical men have not yet appreciated the fact that the operation is itself responsible for the dissemination of the disease by its local infection. Theoretically, the surgeons are responsible for post-operative local infections, and doubt. less in many instances they are. But practically, local infections, at the time microscopic, may not be their fault. It is a risk, a small one in competent hands, that the patient must take when undergoing an operation for carcinoma or tuberculosis. These local infections are not secondary metastatic growths in the ordinary sense of the word, and if recognised early need not of necessity affect the prospect of metastatic and fatal recurrences, provided that they are quickly and freely removed.

Recognising that post-operative local infection can occur without necessary incompetence on the part of the surgeon or medical man, it is desirable that every such operation area should be examined by the medical attendant from time to time; for instance, at first every fortnight then every month, then two months, and so on, the intervals becoming longer and longer and all suspicious nodules and thickenings being excised. In this way local infections are removed at once and not allowed to linger until they have done harm. I am, Sirs, yours faithfully, Harley-street, W., Nov. 9th, 1907. EDRED M. CoRnER.

\section{RICE AND BERI-BERI. \\ To the Editors of THE LANOET.}

SIRs,-Your number of June 29th, 1907, contains an article on Rice and Beri-beri by Dr. William Fletcher. His very interesting experiments are a confirmation of my own made in Cochin-China in 1898 and described in a pamphlet published by Baillière (Paris) in 1905.

My opinion was that rice is the great factor of beri-beri, being the medium wherein the pathogenic bacteria grow, but I found out that fresh, cured, and "red" rice-i.e., rice with its perisperm on) were equally harmless in spreading beriberi, the reason being that the bacteria were killed in asepticised or cured rice, it has not the time to grow on fresh rice and it cannot grow on the red kind. This pamphlet was duly sent to THE LANCET and acknowledged under the heading, "Books, \&c., Received." I know enough of the British love of fair play to feel sure that you will consider my claim to priority and be kind enough to insert this letter in your valuable paper, and believe me, yours very truly, Dr. Dubruel De Broghio.

\section{CHANCRE OF THE CERVIX.}

\author{
To the Editors of THE LANCET.
}

SIRS,-In the course of your review of Dr. F. J. McCann's "Cancer of the Womb," I notice the following: "We are told that a hard chancre on the cervix is not rare; this statement is not supported by any proof and is contrary to the experience of most gynæcologists, at any rate at that period of life in women at which cancer usually affects the cervix." In my "Differential Diagnosis of Syphilitie and Non. syphilitic Affections of the Skin" I wrote that, "as to the cervix it is an error to suppose that the chancre is very rare in this situation. On the continent, where women are examined more thoroughly than is the case with us, it is not uncommon, so that an examination with a speculum in a good light should not be neglected if it can possibly be managed when necessity arises." I am therefore in agreement with Dr. McCann's general statement. With regard to your reviewer's qualification as to the age period of cancer of the cervix there is something in that, but it may be remarked that a chancre of the cervix may, of course, occur at any age. I should like to refer to what Fournier says in his "Syphilis chez la Femme" (second edition, 1881, p. 53) :-

Le chancre du col passe pour une rareté pathologique. M. Clerc, dans sa statistique, n'en mentionne qu'un seul cas sur un total de 113 chancres de diverses régions. M. Carrier ne le cite même pas dans la sienne. Les traités de gynécologie s'en préoccupent à peine, et certains même le passent sous silence. Bref, de l'aveu général le chancre utérin serait une lésion véritablement exceptionnelle. Je proteste énergiquement pour ma part et contre ces statistiques et contre cette croyance commune. Si je consulte en effet mes ouvenirs, je suis bien certain d'avoir rencontré le chancre utérin a'une façon assez fréquente. Bt si je m'en rapporte à mes notes, je trouve, sur un total de 249 chancres génitaux, 13 cas de chancres du col ; ce qui donne une proportion d'un chancre du col contre 18 chancres d'autres régions.

In his list (p. 52) primary chancre of the cervix uteri comes fourth, viz. :-

Labia majora

Labia minora...

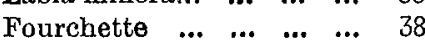

$\begin{array}{llllll}\text { Cervix uteri } & \ldots & \ldots & \ldots & \ldots & 13\end{array}$

Clitoridean region $\quad \ldots \quad \ldots \quad 10$

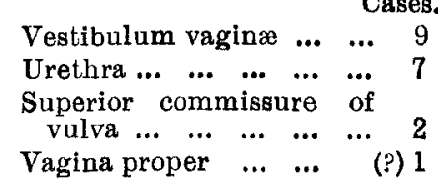

In Ricord's Atlas (1851), Plate V., there is an instructive case of chancre of the cervix discovered by Ricord, notwith standing the fact that another medical man who had examined the patient positively asserted there was no sign whatever of syphilis about her. Ricord wittily remarks :-

Que d'erreurs de ce genre avant que je n'eusse vulgarisé l'emploi du spéculum dans l'étude des maladies vénériennes! Que d'erreur 